\title{
THE EFFECTIVENESS OF DISCOVERY AND INQUIRY LEARNING STRATEGIES IN IMPROVING STUDENTS' EARLY MATH SKILLS
}

\author{
Rita Mariyana $^{1)}$, Myrnawati Crie Handini ${ }^{2)}$, Maruf Akbar ${ }^{3)}$ \\ ${ }^{1)}$ Universitas Negeri Jakarta, Jakarta, Indonesia \\ E-mail: ritamariyana_paud15S3@mahasiswa.unj.ac.id \\ ${ }^{2)}$ Universitas Negeri Jakarta, Jakarta, Indonesia \\ E-mail: myrnawati@unj.ac.id \\ ${ }^{3)}$ Universitas Negeri Jakarta, Jakarta, Indonesia \\ E-mail: maruf.akbar@unj.ac.id
}

\begin{abstract}
The study aimed to find out the effectiveness of discovery and inquiry learning strategies on the efforts of improving the early math skills of students in kindergartens in West Java Province, Indonesia. This is experimental research. The sampling method was done by multi-stage random sampling with probability sampling and it obtained 72 samples of kindergarten students consisting of 36 children from kindergartens in Bandung, West Java who were treated by discovery learning strategy and 36 children from the kindergartens in West Bandung Regency who was treated using inquiry learning strategy. Data were obtained using a checklist of observation sheets for early math skills of kindergarten children. Data analysis used a quantitative descriptive with a t-test. The findings of the study indicate that discoverylearning strategy is better than inquiry learning strategy in improving early math skills of kindergarten students. It is evidenced by the results showing that the average score of group with discovery learning strategy was 111.63 and the average score of group $\mathrm{n}$ using inquiry learning strategy was 101.96 with the result of t-count of 5.551 at the 0.05 level of significance. The conclusion of this research there were differences in early math skills between groups of children with discovery learning strategy and those with the inquiry learning strategy. From the results of data processing and discussion of the study, it was concluded that discovery learning strategy was better than inquiry learning strategy in increasing the score of early math skills of kindergarten children.
\end{abstract}

Keywords: Early Math Skill; Discovery; Inquiry; Kindergarten

\section{INTRODUCTION}

Kindergarten in the age range of 4-6 years is a sensitive period for children (golden age). Children begin to be sensitive to accepting various efforts to develop their maximum ability. The sensitive period is the period of maturation of physical and psychological functions that are ready to respond to stimulation given by the environment. This period is a time to lay the first foundation in developing the existing talents, skills, or abilities in children. Therefore conditions and stimulation are needed following the needs of the child so that the child's growth and development is optimally achieved (Mariyana, Listiana, \& Zaman, 2019).

Early mathematics had a big effect on human life. Whether we realize it or not, actually a person cannot be separated from mathematics. It can be seen from how adults can solve various problems especially related to mathematical concepts and thinking such as determining the land area, adding the total price of goods purchased, measuring the distance from home to school, and many other examples. However, most people think that mathematics is very hard and difficult.

Based on the Aulia report (2015) that when compared to member countries of the Organization for Economic Cooperation and Development (OECD), the logical ability of Indonesian students is three years behind compared to students from other OECD country members. This logical ability is seen from the ability to read and count. It is often believed that mathematics, especially at the school level, is difficult and unpleasant to learn. The OECD General said that $32 \%$ of children taking the math test could not solve the 
easiest calculation questions. Therefore, without mastering the most basic early math skills, it is predicted that children will drop out of school or will have difficulty in facing real life in their future (Aulia, 2015).

Even in a study by Gewati, she is questioning: "Are Indonesian Students' Math Skills worrying, Any Solution?", (Gewati, 2016). The fear of many students in mathematics subjects can be seen from the results of the Program for International Student Assessment (PISA) survey. The study conducted by the Organization for Economic Cooperation and Development (OECD) on 15-year-old children in 2015, placed the math skills of Indonesian students ranked 63rd out of 72 countries.

The data of the Lokadata Beritagar.id team that processes the results of research at the elementary school level in 2016 shows that Indonesian children's science skills are the worst of the other two subjects. Only 1 percent of 2.29 percent of children is found with "good" scientific abilities. Students with "good" numeracy or math skills were 2.29 percent. In reading skills, 6.1 percent of students are considered to have good reading skills. "Mathematical literacy skills are consistent for PISA and AKSI assessments, it is the lowest compared to other (abilities/skills). This shows students' ability to understand concepts or reasoning is still lacking due to their memorizing habits (Aghnia, 2018).

Research findings (Lee et al., 2015) showed that parents use certain types of cues from mathematical cues related to movements when playing math games with children. The findings of Kinzer, Gerhardt, and Coca (2016) regarding the use of standard building blocks based on mathematical tasks, children have the opportunity to develop important mathematical concepts and mathematical reasoning strategies. Kindergarten teachers can do instructional activities based on history, research, wisdom, and professional knowledge that is appropriate and meaningful for students in mathematics with thinking tools such as building blocks (Kinzer et al., 2016).

Mathematics learning strategies in Early childhood education had not played an important role for many years, therefore, it is very crucial to pay attention to early mathematics learning. There is a broad consensus that mathematics learning in kindergarten is supposed to be more informal than learning in school. Kindergarten teacher services in learning mathematics become more important to ensure coherent early mathematics learning in kindergarten. Therefore, a strong theoretical foundation and professional knowledge to realize early mathematics learning is needed (Gasteiger \& Benz, 2018).

The results of the study of Zippert and Rittle-Johnson (2018) show that home is the best place for children to acquire and to be familiar with early mathematics. So parents should support a variety of early math skills at home such as initial number recognition. Parents' beliefs, especially about their child's academic abilities, can influence the components of the early math environment. Then, further research is needed to find out the relationship between parents' academic beliefs and the mathematics learning environment created (Zippert \& Rittle-Johnson, 2018).

Jumhariyani's research results (2016) showed that guided discovery methods and critical thinking skills can improve math skills. This study aimed to analyze the effect of guided discovery methods and critical thinking skills on math skills.

The Research Questions are as follows: "Is there a difference in early math skills between groups of children with discovery learning strategy and those with inquiry learning strategy?"

The Research Hypothesis states: "There is a difference in early math skill improvement between groups of children with discovery learning strategy and those with inquiry learning strategy ".

\section{METHODOLOGY}

This research used experimental research of quasiexperiment type with a factorial $2 \times 1$ research design. The retrieval of questionnaire observation data from early math skills was constructed by the researcher.

The population in this study were early childhood children aged 5-6 years in West Java. While the study sample was children of Kindergarten Group B (the second year) in Bandung and West Bandung Regency, West Java. The sampling is based on multi-stage random sampling with probability sampling techniques. One sampling technique with probability sampling is simple random sampling. It is said to be simple because it is done randomly regardless of the strata that exist in the population. This way is done if members of the population are considered homogeneous.

There were 72 samples of kindergarten children consisting of 36 children from kindergarten in Bandung, West Java who were treated by discovery learning strategy and 36 children from kindergarten in West Bandung Regency who were treated by inquiry learning strategy.

\section{RESULTS AND DISCUSSION}

After doing the study on the second-year students of kindergartens in Bandung and West Java, there found some findings of the research as presented below:

\section{A. Scores of Early Math Skills of the second-year students with Discovery Learning.}

Based on the data collected from the 72 participants, it is known that the score of the early math skills of the children with this learning strategy was 0-135; the highest score was 135; the lowest score was 93; the average score was 111.63 ; the median was 110.5 ; the mode was 106; and the standard deviation was 10.22 .

\section{B. Scores of Early Math Skills of the second-year students with Inquiry Learning.}

Based on the data collected from the 72 participants, it is known that the score of the early math skills of the children with this learning strategy was $0-135$; the highest score was 118.00 ; the lowest score was 78 ; the average score was 
101.96; median was 104.00; the mode was 108; and the standard deviation was 10.67 .

\section{Results of Data Analysis}

TABLE I

T-TEST OF DISCOVERY AND INQUIRY

\begin{tabular}{llrr}
\hline Strategy group & N & \multicolumn{1}{c}{ Mean } & Std. Deviation \\
\hline Discovery & 72 & 111.63 & 10.22 \\
Inquiry & 72 & 101.96 & 10.67 \\
\hline
\end{tabular}

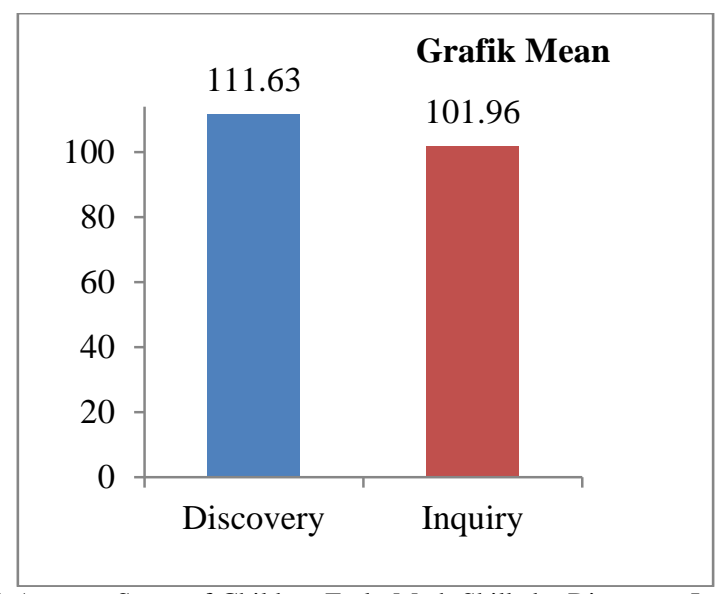

Fig. 1 Average Score of Children Early Math Skills by Discovery Learning Strategies and by Inquiry Learning Strategy

From the results of the data analysis above the average score of children with discovery, learning strategy is 111,625 $\approx 111.63$ and the average score of children with inquiry learning strategy is $101,958 \approx 101.96$; with a t-count value of 5.55 and Sig $0.00<0.05$. This shows that there is a significant difference between the scores of the Early Math Skills of children using the discovery learning strategy and those using the inquiry learning strategy. Based on the avarice score, it can be concluded that discovery-learning strategies are better than inquiry learning strategies in increasing the score of children's early math skills.

The results of research conducted by Salo (2016) aimed at obtaining a learning design using learning methods to improve student learning activeness. The research method used was quasi-experimental. Based on the analysis of the data it was found that there were significant differences in the effect of the learning activeness between the experimental and control groups, (Salo, 2016).

It is in line with the results of the study by Yuliza, Kausar, and Yulia (2016) related to the use of Guided Discovery learning models in improving learning activities and outcomes. Research shows that there is an increase in children's activities.

Moreover, a similar thing also chances with the study by Istikomah (2014) that conducted a study on the development of discovery learning methods to improve students' science understanding for the second year students of kindergarten (TK B). Thus, it can be concluded that discovery learning methods for children's science understanding for the secondyear students of kindergarten (TK B) are valid and effective.
The results of research conducted by Muliani et al. (2017) also strengthens the assumption that discovery learning strategy affects the ability to recognize color in kindergarten students. Likewise, the findings of researchers, proved that a discovery-learning strategy influences the improvement of early math skills in kindergarten students.

Vandalita (2016) research explains that inquiry-based learning models are very ineffective because the teacher and the persons around the children could not give enough stimuli for children in their efforts to find the math problems by themselves. This study also finds out that inquiry learning strategies were less effective in improving early mathematics in kindergarten children.

\section{CONCLUSIONS}

The results showed that there were differences in early math skills between groups of children with discovery learning strategy and those with the inquiry learning strategy. From the results of data processing and discussion of the study, it was concluded that discovery learning strategy was better than inquiry learning strategy in increasing the score of early math skills of kindergarten children.

This recommends for Kindergarten educators and teachers to implement the discovery-learning strategy in the process of mathematics learning in early childhood especially in the starter of early math skills for early childhood. To optimize the early math skills of children, especially children in the second year of kindergarten (TK B) during the learning process, the children are supposed to be actively involved in making observations using their senses, trying to have hands-on experience, expressing their observations, concluding the results of their observations that have been studied, and finally associating it with their daily lives. By doing these, they can solve the problems of their daily life as the main goal of early childhood math learning and following the principles of the application of discovery learning strategy and inquiry learning strategy.

\section{REFERENCES}

Aghnia, A. (2018). Kualitas pendidikan anak Indonesia memprihatinkan. https://beritagar.id/artikel/berita/kualitaspendidikan-anak-indonesia memprihatinkan

Anam, R. S. (2015). Efektivitas dan Pengaruh Model Pembelajaran Inkuiri pada Pembelajaran IPA di Sekolah Dasar. Mimbar Sekolah Dasar, 2(1), 80-89. https://doi.org/10.17509/mimbar-sd.v2i1.1334

Aulia, S. A. (2015). Pengaruh Pendidikan, Pelatihan dan Motivasi Kerja Terhadap Produktivitas Kerja Karyawan. (Pada PT. Inti Sukses Garmindo Semarang). Skripsi. Surakarta: Fakultas Ekonomi, Universitas Muhammadiyah Surakarta.

Gasteiger, H., \& Benz, C. (2018). Enhancing and analyzing kindergarten teachers' professional knowledge for early mathematics education. Journal of Mathematical Behavior, (January), 01 https://doi.org/10.1016/j.jmathb.2018.01.002 
Gewati, M. (2016). Minat Baca Indonesia Ada di Urutan ke60 Dunia. Kompas.com.

Istikomah. (2014). Pengembangan Perangkat Pembelajaran Metode discovery Learning Untuk Pemahaman Sains Pada Anak TK B. Nur El-Islam, 1(52), 81-93.

Jumhariyani. (2016). Pengaruh Metode Penemuan Terbimbing dan Kemampuan Berpikir Kritis terhadap Kemampuan Matematika Siswa Kelas IV Sekecamatan Setiabudi Jakarta Selatan. Jurnal Pendidikan Dasar, 7(1), 62-73.

Kinzer, C., Gerhardt, K., \& Coca, N. (2016). Building a Case for Blocks as Kindergarten Mathematics Learning Tools. Early Childhood Education Journal, 44(4), 389-402. https://doi.org/10.1007/s10643-015-0717-2

Lee, J., Kotsopoulos, D., Tumber, A., \& Makosz, S. (2015). Gesturing about number sense. Journal of Early Childhood Research, 13(3), 263-279. https://doi.org/10.1177/1476718X13510914

Mariyana, R., Listiana, A., \& Zaman, B. (2019). Design of Learning Environment for Children's Basic Character Development. In Character Education for 21st Century Global Citizens (pp. 467-471).
Taylor \& Francis Group London.

Mutiara, S. (2017). Profil Kompetensi Early Math Anak Usia 5-6 Tahun (Studi Deskriptif Pada Anak Usia 5-6 Tahun di TK Azahra Kota Bandung). Golden Age Jurnal Pendidikan Anak Usia Dini, 1(1), 59-65.

Salo, A. Y. (2016). Pengaruh Metode Discovery Learning Terhadap Keaktifan Belajar Siswa (Studi Quasi Eksperimen Kelas Vii Smpn 6 Banda Aceh). Jurnal Penelitian Pendidikan, 16(3), 297-304.

Vandalita, M. T. (2016). Pengembangan Perangkat Model Pembelajaran Berbasis Inkuiri (Inquiry Based Learning). Proceeding Biology Education Conference, 13(1), 2528-5742.

Yuliza, R., Kausar, \& Yulia, A. (2016). Mimbar Pendidikan. Jurnal Indonesia untuk Kajian Pendidikan, 2(1), 19-32. https://doi.org/10.1016/j.apenergy.2015.03.087

Zippert, E. L., \& Rittle-johnson, B. (2018). The home math environment: More than numeracy. Early Childhood Research Quarterly. https://doi.org/10.1016/j.ecresq.2018.07.009 